\title{
Evidence and lessons learned regarding the effect of equitable quality education on 'open society'
}

\author{
Astrid Fieldsend \\ Education Development Trust \\ May 2021
}

\section{Question}

What evidence exists and what lessons can be learned regarding the effect that equitable quality education' has on 'open society'?

The concept of 'open society' is broad. For the purposes of this review, the following areas will be of focus: (1) impact of education on democracy; (2) impact of education on civic engagement; (3) impact of education on social cohesion.

\section{Contents}

1. Summary

2. Impact of education on democracy

3. Impact of education on civic engagement

4. Impact of education on social cohesion

5. Lessons learned

\footnotetext{
${ }^{1}$ For the purposes of this report, 'quality equitable education' refers to schooling for school-age children.

2 For the purposes of this report, FCDO has provided a definition of 'Open Society' which can be found in the summary section.
}

The K4D helpdesk service provides brief summaries of current research, evidence, and lessons learned. Helpdesk reports are not rigorous or systematic reviews; they are intended to provide an introduction to the most important evidence related to a research question. They draw on a rapid deskbased review of published literature and consultation with subject specialists. other Government departments, but the views and opinions expressed do not necessarily reflect those of FCDO, the UK Government, K4D or any other contributing organisation. For further information, please contact helpdesk@k4d.info. 


\section{Summary}

The purpose of this review is to assist FCDO in understanding the evidence of impact and any valuable lessons regarding the effect equitable quality education can have on 'open society'.

FCDO provided a definition of 'open society'. It comprises:

- Institutions: Citizens benefit from stronger, more accountable, and inclusive institutions: democratic elections and transitions; parliamentary systems; public finance and administration; and security and justice.

- Transparency and accountability: The conduct of government is underpinned by freedom of expression, inclusive and open digital and media spaces; strong and engaged civil societies; resilience to corruption and illicit finance, and a robust legal and regulatory system.

- Human rights: Individuals, particularly from marginalised groups, have greater protection in relation to their human rights. Governments and non-governmental actors are held accountable for abuse and neglect of human rights.

As the definition was broad, the first step was to carry out literature search to establish the strength of evidence in the different areas. The search revealed that there is a considerable volume of evidence which focuses on education's ability to reduce poverty, increase economic growth, boost employability and achieve better health outcomes. There is less which focuses on the aspects of 'open society' as defined in this paper. The scope of this review was narrowed to focus upon areas of the 'open society' definition where the most evidence does exist, given the timeframe for the review. The scope was narrowed to focus on:

- Democracy - more accountable and inclusive institutions, democratic elections and transitions, parliamentary systems, public finance, and levels of corruption.

- Civic engagement - strong and engaged civil societies.

- Social cohesion - protection for marginalised groups, security, and justice.

The review of the literature found strong evidence that equitable quality education can have a range of positive impacts on democracy (specifically, its institutions and processes), civic engagement and social cohesion.

The report will look at the evidence in each area in turn (democracy, civic engagement, and social cohesion). The strength of the evidence is assessed, and lessons learned are identified. There is considerable conceptual overlap between each area (for example, civic engagement is a cornerstone of democracy) and as such, there is the potential for some crossover between sections. However, each section has been cross-referenced in an attempt to limit duplication.

There is a considerable body of evidence which indicates that there is a correlation between equitable quality education and benefits to societies (more peaceful, higher levels of trust, greater participation in politics, etc). However, there was no clear evidence that investment in equitable quality education directly leads to positive societal outcomes. This is because there are so many other factors to account for in attempting to prove causation. 
The lack of rigorous studies which attempt to attribute causation demonstrates a clear evidence gap.

It is important to note that education systems themselves are politicised and cannot be divorced from the political process. The extent to which education can impact positively on open society depends a great deal on the value education has within the political system in which it is operating.

\section{Impact of education on democracy}

The hypothesis that access to education leads to greater levels of democracy within societies has significant empirical support (Barro, 1999; Glaeser, LaPorta, Lopez-de-Silanes, and Schleifer, 2004; Papaioannou and Siourounis, 2005). Glaeser et al compared the Polity IV Index of Democracy (Jaggers and Marshall, 2003) and the years of schooling in country in 1960 (Barro and Lee, 2001). Across 91 countries, the correlation coefficient between the variables is $74 \%-a$ strong correlation. Though correlation does not prove causation, the data also demonstrated that increased levels of schooling led to countries transitioning from other systems (such as authoritarian) to democracy (Glaeser, 2007).

Evidence suggests that citizens with higher levels of education are more likely to believe that living in a democratic country is important and are therefore more likely to be interested in preserving and promoting democracy throughout their lifetimes. The World Bank (2018) survey of more than 30 developing countries supports this, as does data from the Global Monitoring Report (UNESCO, 2014). Across 18 sub-Saharan African countries, those of voting age with primary education were 1.5 times more likely to express support for democracy than those with no education. However, it is important to note that this is not always the case. In Kenya, although greater levels of education had caused young women to have increased levels of political knowledge, it also 'led them to be more disenchanted and more accepting of political violence' (World Bank, 2018).

Evidence suggests that citizens with higher levels of education have higher levels of trust and tolerance. Findings from OECD research indicated that better educated individuals are more trusting and tolerant of people they know and even of strangers (OECD, 2015). Citizens with higher levels of trust in government are more likely to comply with paying their taxes (Scholz and Lubell, 1998) and be in greater support of the way the government spends those taxes (Chanley et. al, 2000; Heatherington, 2004). Additionally, trust in institutions like banks tended to be higher; an important factor in securing greater financial stability at a societal level (OECD, 2015).

Education creates the building blocks for inclusive institutions which are a key tenet of democratic societies. Chong and Goldstein (2015) contend that greater levels of civic agency (discussed in more detail in the following section) leads to more inclusive institutions and stronger social contracts between citizens and their governments. The World Development Report (2018) highlights the virtuous circle that can be created as a result of this: more engaged and active citizens are more likely to be supportive of further investment in and reform of education. The World Development Report also found that education improves institutions and public services. 'Educated parents are better able to leverage decision-making at the school level' and 'a more educated population generally demands more transparent use of public 
resources, better service delivery, and government accountability'. In fact, countries that had achieved 'mass education by 1870 had less corruption in 2010' (World Bank, 2018).

\section{Education is likely to strengthen democracy because it emphasises the benefits of} political activity. This is tightly related to political participation and so is therefore discussed in detail in the following section.

\section{Impact of education on civic engagement}

The hypothesis is that increased levels of education promotes and strengthens democracy because it promotes civic behaviours such as voting which underpin the democratic process.

Scholars have devoted considerable resources in trying to understand what drives civic participation (Mayer, 2011). It has become accepted wisdom that education and levels of education are a key determinant of levels of civic participation because education 'encourages citizens to participate in democratic processes and prepares them to do so in an informed and intelligent manner' (Dee, 2004). Furthermore, pedagogical approaches in schools teach people to interact with each other (Glaeser, 2007), which supports the behaviours needed to participate in civic matters. The volume of evidence in this area demonstrates a strong correlation between educational attainment and various civic behaviours, in particular, that higher levels of schooling are associated with substantive increases in voter turnout (Dee, 2004). This view has not been significantly challenged (Nie and Hillygus, 2001), however, recent research suggest that not enough has been done to account for other factors which might influence participation (Dee, 2004; Mayer, 2011). In fact, much of the research on the impact of education on strong and engaged civil societies fails to assign causality.

\section{Nonetheless, levels of education and civic engagement are correlated:}

- In 14 Latin American countries, voter turnout was five percentage points higher for those with primary education and nine points higher for individuals with secondary education than for those with no education (UNESCO, 2014).

- Across 29 mostly high-income countries, $25 \%$ of people with less than secondary education expressed concern for the environment compared with $37 \%$ of people with secondary education and $46 \%$ of people with tertiary education (UNESCO, 2014).

- In Latin America, people with secondary education were $47 \%$ less likely than those with primary education to express intolerance for people of a different race (UNESCO, 2014).

- In the Arab States, people with secondary education were $14 \%$ less likely than those with only primary education to express intolerance towards people of a different religion (UNESCO, 2014).

- In Ethiopia, six years of education increased by $20 \%$ the chance that a farmer would adapt to climate change through techniques such as practising soil conservation, varying planting dates and changing crop varieties (UNESCO, 2014).

- Levine et al (2008) observed that women with higher levels of education tend to participate more in civic and political life, citing a number of examples of women using political movements to secure benefits for themselves. 
- In the United States, getting more education - for example, as a result of pre-school programs, high school scholarships or smaller class sizes - leads people to vote more often (World Bank, 2018).

- In Benin, receiving more education made people more politically active over their lifetimes (World Bank, 2018).

- In Nigeria, educational expansion substantially increased the civic and political engagement of its beneficiaries decades later (World Bank, 2018).

There is a considerable amount of literature which focuses on how investment in specific activities related to civic engagement can have long-lasting effects on individuals' attitudes towards participation throughout their lifetime. Providing specific opportunities for young people to engage in decision-making has been shown to improve their problem-solving, negotiation and communication skills, enables them to build better relationships (Generation Unlimited 2020; Martin, 2015), and leads to policies and decisions that are more likely to address their needs. In turn, young people are then able to utilise these skills to 'strengthen civil society, increase accountability of governments and corporations and work towards greater social cohesion' (Generation Unlimited; Gaventa, O’Kane).

Glaeser (2007) notes that 'the most dramatic place to see the effect of education on political participation is student activism', noting students rioting against authority in 'Oxford, Bologna and Paris even in the Middle Ages' and that students played key roles in 'liberal movements and revolutions in Europe in the middle of the $19^{\text {th }}$ Century' (Glaeser, 2007). Students were also often at the centre of social movements and protests during the $20^{\text {th }}$ Century and early $21^{\text {st }}$ Century: for example, student demonstrations played an important role in the overthrow of Peron in Argentina in 1955, in the Tiananmen Uprising of 1989, and in peaceful demonstrations in Ukraine (Glaeser, 2007). It is important to note that student activism does not always show a preference for democracy. Both Mussolini and Hitler relied on student movements for support. As noted in the summary, education systems are part of the political economy. As such, students who experience that political economy will be reacting to it. Collinson (2003) describes "the interaction of political and economic processes in society: the distribution of power and wealth between different groups and individuals and the processes that create, sustain and transform these relationships over time".

Korin (2020) found that countries with well-educated women enjoy the greatest returns to civic engagement and social commitments. There is consensus in the literature is that investment in education for women and girls has a multiplier effect on society as a whole. Evidence from Levine et al. (2008) points specifically to an increased likelihood of democratic governance in countries with well-educated women.

\section{Impact of education on social cohesion}

The hypothesis is that a more equal society in which fewer people find themselves on the 'outside' leads to greater civic engagement and citizens who are more willing to hold government and institutions to account. Therefore, educational initiatives and interventions which seek to increase social cohesion have the potential to yield significant benefits to society. 
There is very little rigorous research on the direct impact of education on social cohesion and practices of exclusion in society. Social cohesion and exclusion in society are complex, multi-sector challenges that require coordinated cross-sector responses. Because of this, efforts to find causation are challenging as there are so many variables at play. Nonetheless, education can play a significant role in fostering and encouraging social cohesion.

Education improves tolerance and can reduce crime. Higher levels of formal, general education promote trust and tolerance (Korin, 2020). The World Values Survey in Latin America and the Arab states demonstrates that people with primary education only were more likely to demonstrate intolerance towards people of different religion, sexuality and ethnicity than people with secondary education or above. Trust in others increased with additional years of schooling (UNESCO 2014a).

Poor educational attainment is a cause and a consequence of child marriage. Countries with the greatest gender disparities in secondary enrolment include the countries with the highest rates of child marriage (Wodon et al. 2017). Education reduces rates of child marriage, which disproportionately affects girls (Wodon et al 2017).

Tippett and Wolke (2014) found that low socioeconomic status is associated with a greater likelihood of being involved in bullying, either as a bully or a victim. Parents' educational attainment is one of the most important predictors of school performance and educational attainment (OECD, 2020; OECD 2016; Dubow, Boxer and Huesmann, 2009). Data from PISA showed that the students with at least one parent who completed upper-secondary or postsecondary non-tertiary education are less likely to report being victimised (OECD, 2020). The data also shows that low performers, especially boys and students whose parents are less educated, tend to report greater exposure to bullying (OECD, 2017).

As already mentioned in this report, education systems themselves are not capable of being politically neutral. Curricula can play an important role in improving or worsening social cohesion (Naylor, 2015). There are examples of curricula which have been used to oppress particular ethnic groups and to promote hatred, xenophobic and racist ideologies, militarism and religious warfare (Dupuy, 2008). There are also examples of curricula which have been designed to 'promote peace: through direct teaching of peace education, or other subjects promoting tolerance, cooperation and negotiation skills...through subjects that aim to promote civic values and governance, or through inclusive approaches to choice of language of instruction, history and social studies curricula' (Naylor, 2015) 


\section{Lessons learned}

The following tables summarise the evidence alongside lessons learned for each of the three areas.

\section{Democracy}

\begin{tabular}{ll}
\hline Evidence & Lessons for consideration \\
\hline $\begin{array}{l}\text { Increased years of schooling is correlated } \\
\text { with increased likelihood of democratic } \\
\text { politics. }\end{array}$ & $\begin{array}{l}\text { Expand equitable access to quality education, } \\
\text { focusing on measures to support more years } \\
\text { in school. }\end{array}$ \\
$\begin{array}{l}\text { Education in likely to increase democracy } \\
\text { because it creates the conditions for } \\
\text { individuals to be engaged in society. }\end{array}$ & Expand equitable access to quality education. \\
\hline
\end{tabular}

\section{Strong and engaged civil societies}

\section{Evidence}

Levels of education and civic engagement are correlated.

Giving school-age children the opportunity to engage in decision-making and other civic engagement skills is likely to lead to higher levels and more sustained participation in later life.

Finding opportunities for young people to engage in civic processes within their existing environments (through school councils or debating in class, for example) can be low-cost and high impact.

The history of student activism shows that students do not necessarily prioritise advocating for democracy.

There is an increased likelihood of democratic governance in countries with well-educated women.

\section{Lessons for consideration}

Expand equitable access to quality education for all.

Promote and even make compulsory civic education across stages and types of school to close the inequality gap in civic participation in later life.

Train, support and empower system leaders/policymakers to promote and enable schools to facilitate civic education and to foster debate and discussion in classrooms.
Combine civic engagement skills with education on social issues and differing political systems.

\section{Focus on girls' education.}




\section{Social cohesion}

\begin{tabular}{ll}
\hline Evidence & Lessons for consideration \\
\hline $\begin{array}{l}\text { Education can play a significant role in } \\
\text { fostering and encouraging social cohesion. }\end{array}$ & $\begin{array}{l}\text { Expand equitable access to quality education } \\
\text { for all. }\end{array}$ \\
\hline $\begin{array}{l}\text { Trust and tolerance can be increased with } \\
\text { additional years of schooling. }\end{array}$ & $\begin{array}{l}\text { Consider measures to support children and } \\
\text { young people to stay in school for longer. }\end{array}$ \\
\hline $\begin{array}{l}\text { Countries with the biggest gender disparity } \\
\text { in secondary enrolment have the highest } \\
\text { rates of child marriage. }\end{array}$ & $\begin{array}{l}\text { Reduce the disparity between girls and boys } \\
\text { in secondary school enrolment. }\end{array}$ \\
\hline $\begin{array}{l}\text { Children whose parents have lower levels of } \\
\text { education are more likely to be bullied. }\end{array}$ & $\begin{array}{l}\text { Consider measures to support children and } \\
\text { young people to stay in school for longer. }\end{array}$ \\
\hline $\begin{array}{l}\text { The content of curricula can have a positive } \\
\text { or negative impact on society. }\end{array}$ & $\begin{array}{l}\text { Train, support and empower policymakers, } \\
\text { education advisers, teachers etc to design } \\
\text { curricula that support positive social } \\
\text { outcomes. }\end{array}$ \\
\hline
\end{tabular}

The evidence assembled in this report emphasises the importance that a good quality education must be made accessible to all. Education's unique potential to help society achieve other goals can only be fully realised if education is both equitable and of good quality. 


\section{References}

Barro, R. (1999), 'Determinants of democracy', Journal of Political Economy, 107, 158-183. Available at: http://nrs.harvard.edu/urn-3:HUL.InstRepos:3451297

Barro, R., \& Lee, J.-W. (2001). International data on educational attainment: Updates and implications. Oxford Economic Papers, 53, 541-563. Available at: https://www.nber.org/system/files/working_papers/w7911/w7911.pdf

Chanley, V., Rudolph, T. J., Rahn, W. M. (2000), "The origins and consequences of public trust in government: A time series analysis", The Public Opinion Quarterly, Vol. 64, pp. 239-256

Collinson, S. (2003). Power, Livelihoods and Conflict: Case Studies in Political Economy Analysis for Humanitarian Action. London. Humanitarian Policy Group, Overseas Development Institute. Available at: http://www.odi.org.uk/resources/download/241.pdf

Dubow, E.F., Boxer, P., and Huesmann, L.R. (2009). Long-term Effects of Parents' Education on Children's Educational and Occupational Success: Mediation by Family Interactions, Child Aggression, and Teenage Aspirations. Merill-Palmer Quarterly 55(3), pp. 224-249. Available at: https://muse.jhu.edu/article/266848

Dupuy, K. (2008). Education for peace: building peace and transforming armed conflict through education systems. Save the Children and PRIO. Available at:

http://www.prio.org/Publications/Publication/?x=187

Gaventa, J., 'Towards Participatory Governance: Assessing the transformative possibilities' in Participation: From Tyranny to Transformation, edited by Samuel Hickey and Giles Mohan, Zed Books, London, 2004, pp.25-41. Available at:

https://www.researchgate.net/publication/240619950_Towards_Participatory_Local_Govern ance_Assessing_the_Transformative_Possibilities_Prepared_for_the_Conference_on_Parti cipation_From_Tyranny_to_Transformation_Manchester_27_-_28_February_2003

Generation Unlimited (2020), Young people's participation and civic engagement https://www.generationunlimited.org/media/3021/file/Action\%20Guide\%205:\%20Young\%20 people\%E2\%80\%99s\%20participation\%20and\%20civic\%20engagement.pdf

Glaeser, E. L., LaPorta, R., Lopez-de-Silanes, F., and Schleifer A. (2004). Do institutions cause growth? Journal of Economic Growth, 9, 271-303. Available at: https://scholar.harvard.edu/files/shleifer/files/do_institutions_cause_growth.pdf

Glaeser, E. L,, Ponzetto, G. A. M., Schleifer, A. (2007), Why does democracy need education https://scholar.harvard.edu/files/glaeser/files/democracy_final_jeg_1.pdf

Heatherington, M. J. (2004), Why Trust Matters: Declining Political Trust and The Demise of American Liberalism, University Press, Princeton, New Jersey. https://www.jstor.org/stable/j.ctv301fkq 
Jaggers, K., \& Marshall, M. (2003). Polity IV project. Center for International Development and Conflict Management, University of Maryland. Available at:

https://www3.nd.edu/ mcoppedg/crd/PolityIVUsersManualv2002.pdf

Korin, A (2020), Socio-economic impact analysis of education in Nepal Study 2: Analysis of the social impact of education.

Levine, R., Lloyd, C., Green, M., Grown, C. (2008) Girls count: a global investment \& action agenda. Washington, DC: Center for Global Development, 2008. Available at:

https://www.cgdev.org/sites/default/files/archive/doc/annualreports/CGD_Annual_Report_Sp reads.pdf

Mayer, A.K, 'Does Education Increase Political Participation?' The Journal of Politics, Vol. 73, No. 3 (Aug. 3, 2011), pp. 633-645 (13 pages) Published By: The University of Chicago Press

Martin, S et. Al,. (2015) 'An examination of Children and Young people's Views on the impact of their participation in Decision-Making', Department of Children and Youth Affairs, Ireland. Available at:

https://www.researchgate.net/publication/282098595_An_examination_of_children_and_you ng_people's_views_on_the_impact_of_their_participation_in_decision-making

Naylor, R. (2015). Curriculum development in fragile states to encourage peace and reduction of conflict. GSDRC Helpdesk Research Report 1313. Birmingham, UK: GSDRC, University of Birmingham. Available at: https://gsdrc.org/wp-content/uploads/2015/12/HDQ1313.pdf

Nie, Norman and D. Sunshine Hillygus. "Education and Democratic Citizenship," in Making Good Citizens: Education and Civil Society, Diane Ravitch and Jospeh P. Viteritti, editors, New Haven: Yale University Press, 2001.

Novelli, M., Higgins, S. Ugur, M. and Valiente, O. (2014). The political economy of education systems in conflict-affected contexts. Education rigorous literature review. DFID https://eppi.ioe.ac.uk/cms/Portals/0/PDF\%20reviews\%20and\%20summaries/Political\%20Ec onomy\%20Education\%202014\%20Novelli\%20report.pdf?ver=2014-11-24-104035-650

OECD (2015), 'The Educational Roots of Trust', OECD Working Papers No. 119 https://doi.org/10.1787/19939019

OECD (2007), "Education and Civic Engagement: Review of Research and a Study on Norwegian Youths", OECD Working Papers No. 12 https://doi.org/10.1787/19939019

OECD (2016), Education at a glance 2016: OECD Indicators, OECD Publishing, Paris. Available at: https://www.oecd-ilibrary.org/education/education-at-a-glance-2016_eag-2016-en

OECD (2016), Society at a glance 2016: OECD Social Indicators, OECD Publishing Paris.

Available at: https://www.oecd-ilibrary.org/social-issues-migration-health/society-at-a-glance2016_9789264261488-en

OECD (2017), "Bullying”, in PISA 2015 Results (Volume III): Students' Well-Being, OECD

Publishing Paris. Available at: https://doi.org/10.1787/9789264273856-en 
OECD (2017), How's Life? 2017: Measuring Well-Being, OECD Publishing Paris. Available at: https://doi.org/10.1787/23089679

OECD (2020), "How are social outcomes related to education?", in Education at a Glance 2020: OECD Indicators, OECD Publishing, Paris. Available at:

https://www.oecd.org/education/education-at-a-glance-19991487.htm/?refcode=20190209ig

O'Kane, C. 'Children and Young people as Citizens, Partners for Social Change' (2003), Save the Children South and Central Asia. Available at:

https://resourcecentre.savethechildren.net/node/1773/pdf/1773.pdf

Papaioannou, E., \& Siourounis, G. (2005). Economic and social factors driving the third wave of democratization. Mimeo, London Business School. Available at:

https://ideas.repec.org/a/eee/jcecon/v36y2008i3p365-387.html

Scholz, J. T. and Lubell, M. (1998), "Trust and taxpaying: Testing the heuristic approach to collective action" American Journal of Political Science, Vol 42, pp. 398-417. Available at: https://doi.org/10.2307/2991764

Tippet, N., and Wolke, D. (2014), 'Socioeconomic status and bullying: A meta-analysis', American Journal of Public Health. Vol 104/6, pp. e48-e59. Available at: https://ajph.aphapublications.org/doi/10.2105/AJPH.2014.301960

UNESCO (2014a) Education For All Global monitoring report 2013/14. Teaching and learning: achieving quality for all. Paris: UNESCO. Available at: https://en.unesco.org/gemreport/report/2014/teaching-and-learning-achieving-quality-all

UNESCO (2014b). Global Monitoring Report: 'Progress in Getting All Children to School Stalls but Some Countries Show the Way Forward'. Policy Paper, no. 14/Fact Sheet, no. 28. Montreal: United Nations Educational, Scientific and Cultural Organization. Available at: http://uis.unesco.org/sites/default/files/documents/fs28-progress-in-getting-all-children-toschool-stalls-but-some-countries-show-the-way-forward-2014-en.pdf

World Bank, World Development Report 2018: Learning to Realize Education's Promise (Washington, D.C., 2018). Available from:

https://www.worldbank.org/en/publication/wdr2018

Wodon, Q., Male, C., Nayihouba, A., Onagoruwa, A. Savadogo, A., Yedan, A., Edmeades, J., Kes, A., John, N., Murithi, L., Steinhaus, M. and Petroni, S. (2017). Economic Impacts of Child Marriage: Global Synthesis Brief. Washington, DC: The World Bank and International Center for Research on Women. Available at:

https://documents1.worldbank.org/curated/en/530891498511398503/pdf/116829-WP-

P151842-PUBLIC-EICM-Global-Conference-Edition-June-27.pdf 


\section{Acknowledgements}

We thank the following experts who voluntarily provided suggestions for relevant literature or other advice to the author to support the preparation of this report. The content of the report does not necessarily reflect the opinions of any of the experts consulted.

- Astrid Korin, Education Development Trust

- Ruth Naylor, Education Development Trust

\section{Suggested citation}

Fieldsend, A. (2021). Evidence on the effect of equitable quality education on open society. K4D Helpdesk Report. Brighton, UK: Institute of Development Studies. DOI: 10.19088/K4D.2021.094

\section{About this report}

This report is based on six days of desk-based research. The $K 4 D$ research helpdesk provides rapid syntheses of a selection of recent relevant literature and international expert thinking in response to specific questions relating to international development. For any enquiries, contact helpdesk@k4d.info.

K4D services are provided by a consortium of leading organisations working in international development, led by the Institute of Development Studies (IDS), with Education Development Trust, Itad, University of Leeds Nuffield Centre for International Health and Development, Liverpool School of Tropical Medicine (LSTM), University of Birmingham International Development Department (IDD) and the University of Manchester Humanitarian and Conflict Response Institute (HCRI).

This report was prepared for the UK Government's Foreign, Commonwealth and Development Office (FCDO) and its partners in support of pro-poor programmes. Except where otherwise stated, it is licensed for non-commercial purposes under the terms of the Open Government Licence v3.0. K4D cannot be held responsible for errors, omissions or any consequences arising from the use of information contained in this report. Any views and opinions expressed do not necessarily reflect those of FCDO, K4D or any other contributing organisation.

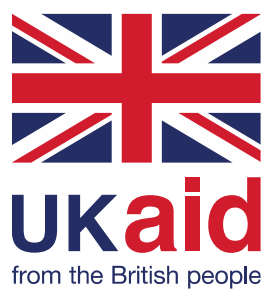

(c) Crown copyright 2021. 